\title{
Application of Spectrometric Gamma-Logging for Specification of Characteristics of Soil Radioactive Pollutions
}

Keywords:

ditches for the foundations of the Arch at the Chornobyl NPP, radioactively contaminated soils, spectrometric gamma-logging of wells,

analysis of the photopic/Compton ratio, determination of the boundary contaminated/clean soils.
The experience of using the method of spectrometric gamma-logging of wells for assessment of radioactive contamination of soils on the sites of foundation pits excavation for the New Safe Confinement foundations is presented in the article. Analysis of the photopic/Compton ratio in the gamma-ray spectra of the wellbore allowed us to identify the types of soil contamination: the volumetric contamination, which is associated with real radioactive contamination, and the surface contamination, which is identified as introduced by drilling. This task is especially relevant for determining the boundaries of contaminated/clean soils, which had an impact on determining the depth of pits and, as a result, on the volume of soils to be developed. The use of spectrometric gammalogging of wells made it possible to correctly predict the categories and volumes of radioactive waste, which were soil to be extracted during excavation. Directions for further improvement of the method of spectrometric gamma-logging to clarify the characteristics of radioactive waste are considered in the article.

\section{Introduction}

The New Safe Confinement (NSC) was created as one of the measures to eliminate the consequences of the Chornobyl disaster in the Chornobyl NPP (ChNPP) area for the order to improve the ecological situation. The soils near the 4th unit of ChNPP are radioactively contaminated and classified as from low to high level radioactive waste. In these soils it was planned to create ditches 3-4 $\mathrm{m}$ deep for the NSC foundations. In fig. 1 the general view of the Shelter object is presented. The northern (1) and the southern (2) zones of foundations (respectively) are to the left and to the right from the Shelter object.

For the planning of excavation technology, radiation safety programs and the radioactive waste management, a need arose for forecasts of the radiation characteristics of industrial soils to be removed during excavation. The forecasts concerned the composition and levels of radionuclide

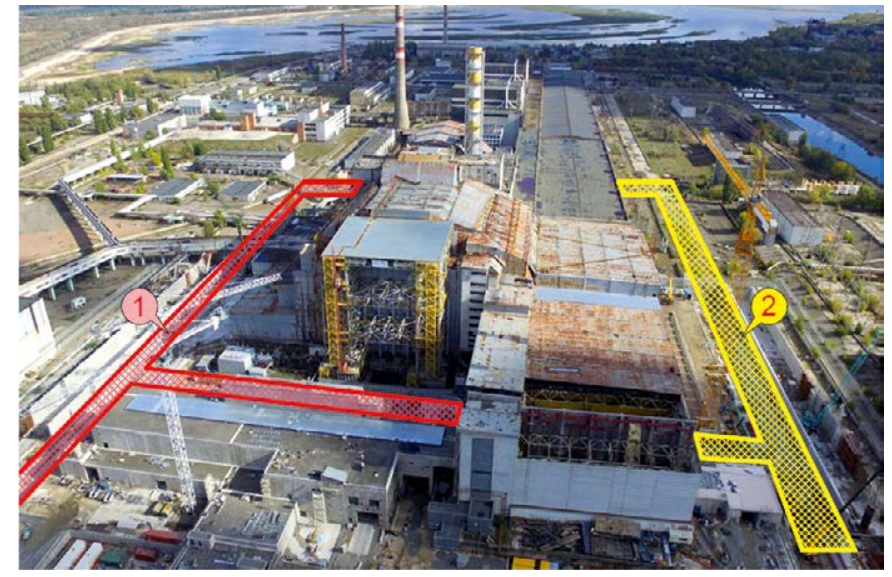

Fig. 1. General view of the Shelter object: 1 - the northern foundation zone; 2 - the southern foundation zone

gamma-logging of wells, which were located on the areas of the pit placement. These are wells of radio-hydroecological monitoring and wells (about 700 wells), which were drilled

(c) O. I. Stoianov, M. I. Panasiuk, V. E. Ivanova, G. V. Levin, N. V. Sosonna, 2020 
in advance on the perimeter of future ditches after $1.5 \mathrm{~m}$ to arrange the sheet pile walls (fig. 2).

The purpose of the article is to summarize the experience of using spectrometric gamma-logging for radioactive waste inventory and to ensure the radiation safety of personnel. Drawing on the experience of using spectrometric gamma-logging, directions for further improvement of this method for refining the characteristics of RW are discussed in the article.

\section{Methodological approach}
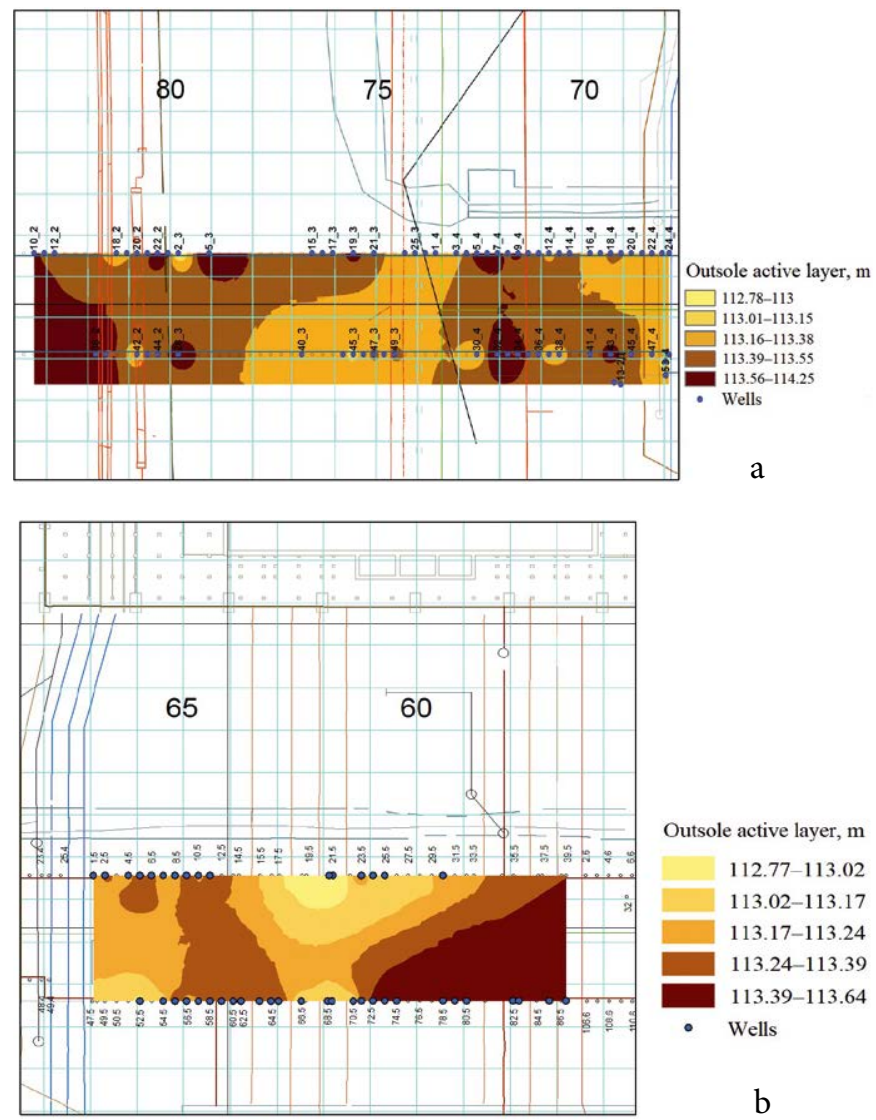

Fig. 2. Schemes of well placement: a - sections 2, 3 and 4; b - section 5 , the southern strip of the foundation NSC with the marks of the sole of the active layer according to the gamma- and spectrometric gamma-logging of the wells

Now and in the coming years, the main source of gamma-radiation, which can serve as an indicator of nuclear fuel in radioactive waste, is the ${ }^{137} \mathrm{Cs}$ isotope. Absolute activity of ${ }^{137} \mathrm{Cs}$ can act as an indicator of fuel content in the measured sample. The reason for the assumption [2] that the form of the spectral distribution of gamma radiation (the ratio of the primary $\mathrm{E}_{\gamma}=0.66 \mathrm{MeV}$ and the $\mathrm{E}_{\gamma}<0.66 \mathrm{MeV}$ Compton scattering of radiation) will depend on the concentration of fuel, is the following.
The process of reducing $\gamma$-radiation with energy $\mathrm{E}_{\gamma}=0.66 \mathrm{MeV}$ occurs due to Compton scattering. The mass coefficient of the Compton reduction practically does not depend on the chemical composition of matter: $\mu / \rho=\sigma_{k} N Z / A$, where $\sigma_{k}$ is the cross section of the Compton scattering, $N$ is Avogadro's number, $\mathrm{Z}$ and $\mathrm{A}$ are the atomic number and element weight $(\mathrm{Z} / \mathrm{A} \approx 0.5$ for $\mathrm{Z} \leq 40, \mathrm{Z} / \mathrm{A} \approx 0.4$ for $\mathrm{U})$. The mass coefficient of photo-absorption depends on $Z: \mu / \rho \approx Z^{5}$. As part of the high-level waste (HLW) of the Shelter, chemical elements with $Z \leq 40$ (soil, concrete and structural materials) and fuel elements $Z \approx 92$ should be expected. For elements with $Z \leq 40$, the attenuation of $\gamma$-radiation is almost entirely determined by Compton scattering, and for heavy elements, with $Z \geq 92$, a significant contribution is to provide photo absorption. The redistribution of mechanisms of the interaction of photons with matter depending on the concentration of heavy elements (uranium) should affect the form of the energy spectrum obtained from the sample of the $\gamma$-emitter. Reduction of the primary $\gamma$-radiation $\left(\mathrm{E}_{\gamma}=0.66 \mathrm{MeV}\right) \mathrm{de}$ pends only on the density of the substance and very little on the concentration of uranium, therefore, the measurement of the absolute activity of ${ }^{137} \mathrm{Cs}$ can be carried out at the peak of total absorption $\mathrm{E}_{\gamma}=0.66 \mathrm{Me} \mathrm{V}$.

This idea was developed in [2]. The mathematical modeling method has been used to study the behavior of this relationship with different well parameters. The results of simulation allow us to conclude that it is possible to divide the inputs of volumetric and surface soil contamination, as well as to determine its specific activity with an acceptable error.

The following expressions were obtained to determine the contribution to the spectral distribution of volume pollution in [3]:

$$
\begin{gathered}
S_{0}=\frac{k_{1}}{k_{0}} \times S_{\mathrm{n}} \times\left(1+k_{0}\right), \\
S_{0}=S-\frac{k_{2}}{k_{\mathrm{n}}} \times S_{\mathrm{n}} \times\left(1+k_{\mathrm{n}}\right),
\end{gathered}
$$

where $S_{0}$ - contribution of volume pollution in the total intensity of radiation in the well; $S_{n}-$ the intensity of the part of the radiation that did not interact $\left(\mathrm{E}_{\gamma}=662 \mathrm{keV}\right)$; $S$ - total radiation intensity in the well; $k_{1}, k_{2}^{\gamma}$ - experimentally determined particles of volumetric and surface pollution in the intensity of part of the radiation that did not interact, respectively; $k_{0}, k_{n}$ - estimated particles of volume and surface pollution in the intensity of the part of the radiation that did not interact, respectively.

The analysis showed that the accuracy of the final results essentially depends on the inaccuracy of the initial data, 
which are experimentally measured in the wells spectra of gamma radiation. Thus, the research carried out by the method of mathematical modeling shows that the form of the $\gamma$-spectrum carries information, the analysis of which allows a simple means to solve a number of problems, namely: determine the concentration of heavy elements in massive samples;

determine the presence of a highly active fragment in a soil with low activity;

determine the contributions of surface and volume contaminants in gamma-logging wells.

Application of the gamma-spectrometric method in solving these problems can increase the accuracy of the definition of the data obtained, reduce the complexity of the work performed, and increase their speed.

\section{Spectrometric gamma-logging to clarify the characteristics of radioactive contamination of soils}

Increased values of the power dose in the range of depths, which are inaccurate technogenic and natural alluvial soils, are noted in some cases [4] in the complex analysis of the results of gamma logging wells in the Shelter object local zone, but these soils must be "clean". That is, the definition of the boundary of contaminated/clean soils according to the gamma logging of the wells has been ambiguous. Since the presence of high radioactivity in these soils is difficult to explain, it was assumed that this phenomenon may be due to the transfer of contamination from the upper layers during the drilling. Contamination of the wellbore (surface contamination) involves the transfer from top to down of the heavily contaminated soil layers of the active particles during drilling and is not related to contamination of the surrounding soil wells (volumetric pollution). For the purpose of practical diagnostics of surface/volumetric pollution the method of spectrometric gamma-logging of wells was applied.

Gamma-spectrometric logging was performed by a well-shaped spectrometric measuring complex with variable detection units, which allows to study the gamma field at separate points of wells in a wide range of power dose values. The spectrometer was developed by the AtomComplexPrylad Company (Kyiv) on the basis of a small-scale specimen of field gamma spectrometer specifically for these purposes. The created amplitude multichannel analyzer "ABA-P" is designed to analyze, accumulate, processe and issue information on pulse amplitude from ionizing radiation detectors to external devices. The device is capable of operating in a wide range of temperatures, in condi- tions of vibration, high humidity and high dust formation.

Measurements were made by two measuring devices:

1) on the basis of crystal $\mathrm{NaI}(\mathrm{Tl})$, size $\varnothing 63 \times 63 \mathrm{~mm}$, for work in fields with the power dose up to $2 \mathrm{mR} / \mathrm{h}$;

2) on the basis of the bismuth germanate crystal $\left(\mathrm{Bi}_{4} \mathrm{Ge}_{3} \mathrm{O}_{12}\right)$, known as $\mathrm{BGO}$, in the size $\varnothing 15 \times 5 \mathrm{~mm}$, for work in fields with the power dose up to $200 \mathrm{mR} / \mathrm{h}$.

Exemplary radioactive sources of ${ }^{137} \mathrm{Cs}$ and ${ }^{60} \mathrm{Co}$ were used to calibrate and evaluate the spectrometric path. In the analysis of the calibration spectra it is determined that the energy resolution for gamma-line ${ }^{137} \mathrm{Cs} 661.6 \mathrm{keV}$ is less than $11 \%$ for a probe based on the crystal $\mathrm{NaI}(\mathrm{Tl})$ and $17 \%$ - for BGO crystal.

The method of detecting surface contamination of the wellbore is based on the differences in the real spectra of the ratios of intensity "photopic/Compton" at the surface and volume distribution of the activity source in the well $[5,6]$ (fig. 3). Fig. 4 shows a diagram of gamma-logging, and in fig. 5 - the spectra obtained in the well $20.4[1,7]$. The left spectrum shows the range that is received on the well bottom. In this well the bottom was much polluted, that is why the spectrum has a high peak of the ${ }^{137} \mathrm{Cs}$ line. The intensity of this peak naturally decreases, in full accordance with expectations, with increasing distance from well bottom as the contribution of scattered radiation increases. However, since this well is much polluted, the peak, which is characteristic for ${ }^{137} \mathrm{Cs}$, remains noticeable on the spectra far from well bottom (see fig. 5).

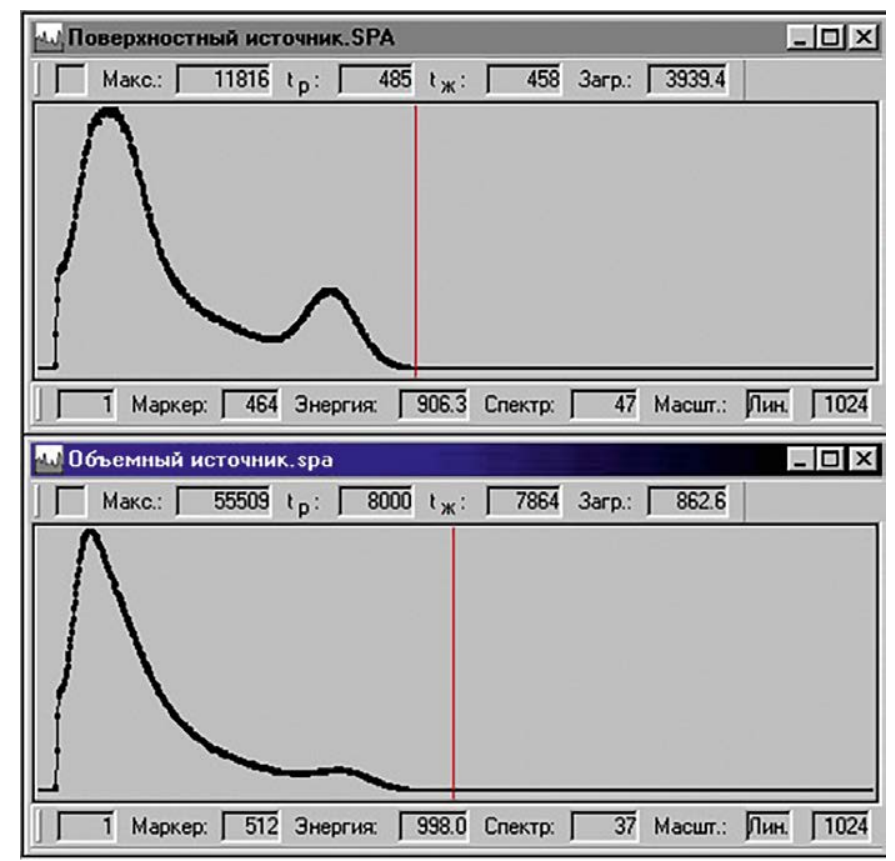

Fig. 3. Standardized and reduced to one scale spectra of the surface and volume sources of gamma radiation 


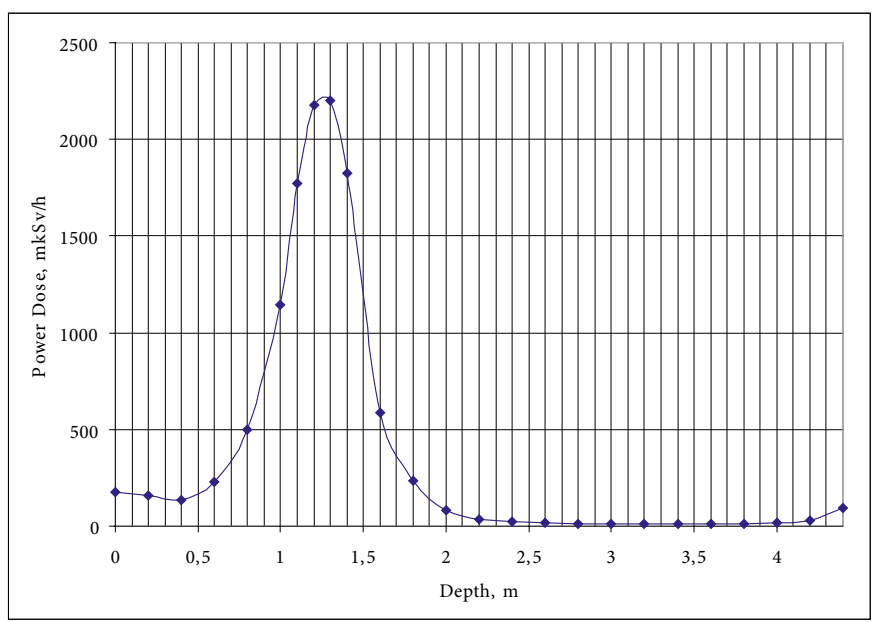

Fig. 4. Diagram of gamma-logging in the well 20.4

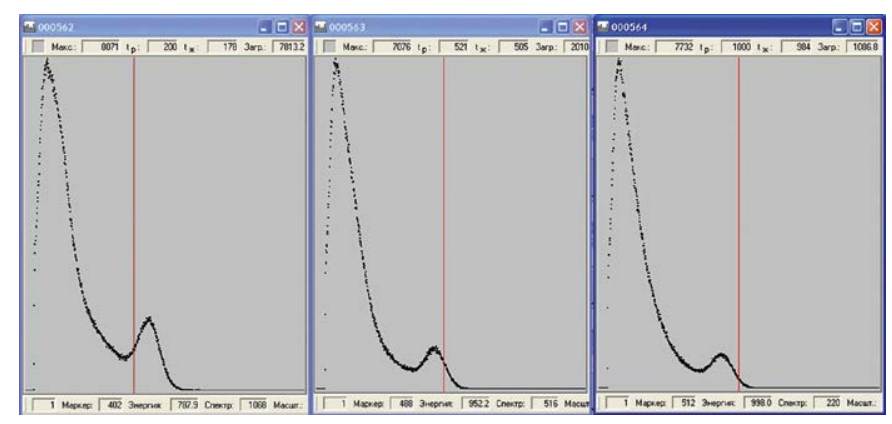

Fig. 5. The spectra obtained in the well 20.4. From left to right: bottom (depth $4.4 \mathrm{~m}$ from the surface); depth $4.2 \mathrm{~m}$; depth of $4.0 \mathrm{~m}[1]$

The results of gamma-spectrometric logging in the wells of foundation pits are presented in digital form in the tab. 1. The results of the analysis of gamma-spectrometric logging for a number of wells show a clear pattern: the increased ratio of "photopik/Compton" is observed on bottom or in the active layer. This ratio decreases at a distance from them, which indicates the relative purity of soils around the well.

The results of gamma-spectrometric logging confirm conclusions about the mechanisms of soil contamination. According to the results of the analysis of gamma-logging data, the following conclusion was made about soil contamination below the active layer. All wells according to gamma-logging can be divided into three classes. In the wells of the first class there are a volume pollution of soils; the second and third classes are polluted in the process of drilling, but around these wells the soil is clean.

The first class is characterized by the presence of a second peak on gamma-logging diagrams, which indicates volumetric contamination of the surrounding wells of soils. These wells are located near communications, which in some cases were uncovered during earthworks.
Table 1. An example of the classification of radioactively contaminated soils and wells based on the results of spectrometric gamma- logging [1]. The location scheme of wells is showed in the fig. 2.

\begin{tabular}{|c|c|c|c|c|c|}
\hline $\begin{array}{c}\text { № of } \\
\text { well }\end{array}$ & $\begin{array}{c}\text { Depth } \\
\text { from } \\
\text { surface, } \\
\text { cm }\end{array}$ & $\begin{array}{c}\text { max/ } \\
\text { Compt }\end{array}$ & $\begin{array}{c}\text { Photopic } \\
\text { of }{ }^{137} \mathrm{Cs}\end{array}$ & ${ }^{137} \mathrm{Cs} / \mathrm{Compt}$ & Note \\
\hline 60.5 & 400 & 25329 & 3373 & 0,13 & $\begin{array}{c}\text { bottom } \\
\text { well, } \\
\text { class }\end{array}$ \\
\hline 60.5 & 250 & 10657 & 1263 & 0,12 & 1 class \\
\hline 59.5 & 250 & 11028 & 417 & 0,04 & 3 class \\
\hline 59.5 & 200 & 9585 & 498 & 0,05 & 3 class \\
\hline 64.5 & 320 & 8176 & 292 & 0,04 & 3 class \\
\hline 64.5 & 300 & 9761 & 399 & 0,04 & 3 class \\
\hline 64.5 & 370 & 11937 & 383 & 0,03 & $\begin{array}{c}\text { bottom } \\
\text { well, } \\
3 \text { class }\end{array}$ \\
\hline 1.4 & 360 & 5548 & 1187 & 0,21 & $\begin{array}{c}\text { bottom } \\
\text { well, } \\
2 \text { class }\end{array}$ \\
\hline 1.4 & 335 & 7950 & 760 & 0,09 & 2 class \\
\hline 20.4 & 440 & 8071 & 1782 & 0,22 & $\begin{array}{c}\text { bottom } \\
\text { well, } \\
2 \text { class }\end{array}$ \\
\hline 20.4 & 420 & 7076 & 922 & 0,13 & 2 class \\
\hline 20.4 & 400 & 7732 & 828 & 0,1 & 2 class \\
\hline
\end{tabular}

The presence of contaminated soils can be explained by the flow of radioactive water from communications of Unit 4 of ChNPP. An example of a well belonging to this group is the well 60.5. Gamma- logging diagram of this well is shown in fig. 6 . The second peak, which is below the active layer, can be seen in this diagram.

The second class is relatively high surface contaminated well walls due to the scattering of active soil particles from the upper heavily polluted layers. Well 20.4 is a typical example of this group. Gamma-logging diagram of this well is presented in fig. 4. From the figure it is clear that the bottom of this well has a significantly larger activity than the wellbore. Based on the data of gamma-spectrometric logging (see fig. 5 and tab. 1), it is possible to see a clear form of photopic ${ }^{137} \mathrm{Cs}$, which, as far as the distance from the bottom takes a more blurred form, that is, the proportion of scattered gamma- quanta passing through the material of the casing increases. So we can make a conclusion about the surface contamination of the bottom. 


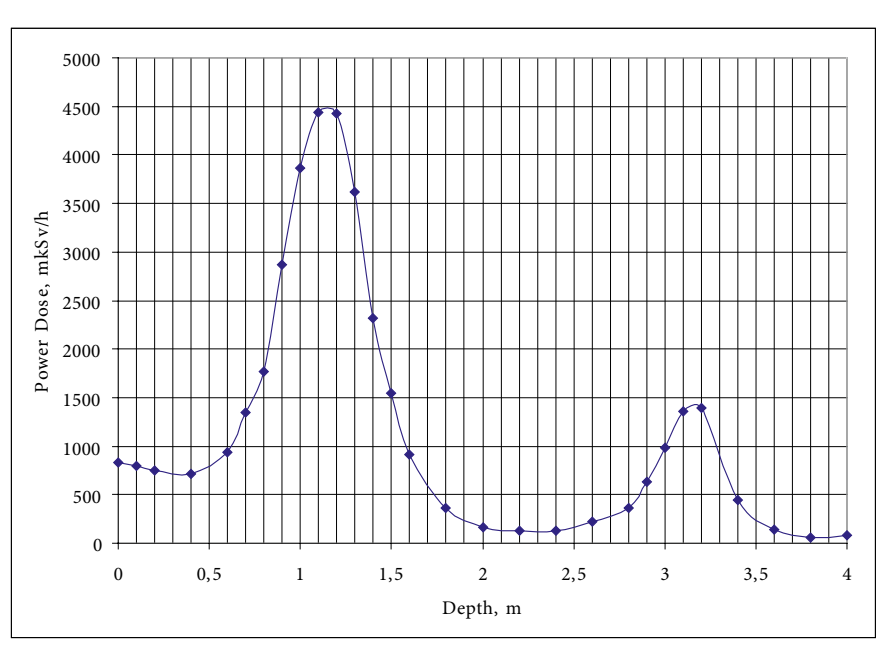

Fig. 6. Diagram of gamma-logging in the well 60.5

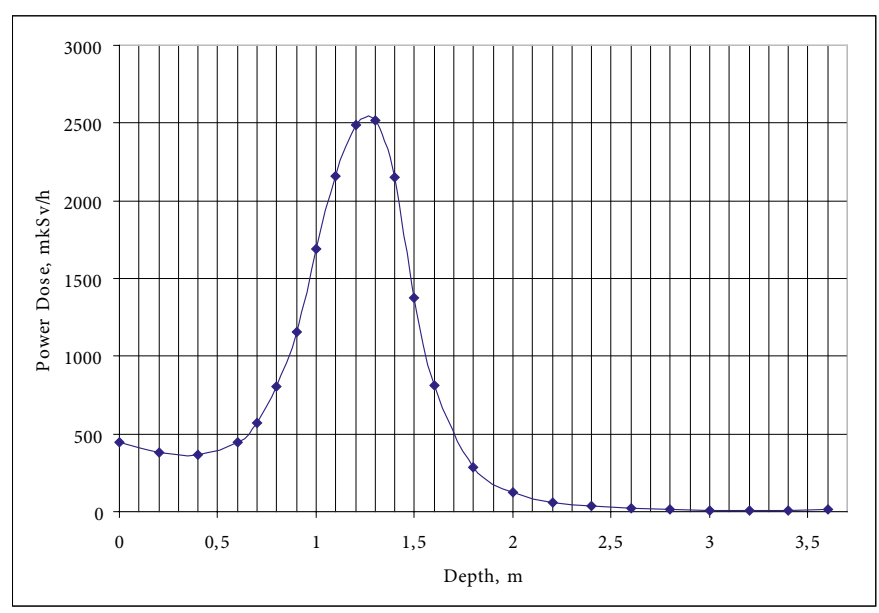

Fig. 7. Diagram of gamma-logging in the well 64.5

The third class - surface contamination of wells is quite insignificant, practically at the level of "background" values. As an example, the well 59.5 and 64.5 are shown in the tab. 1. Diagram of gamma-logging in the well 64.5 is shown in the fig. 7.

\section{Conclusions}

The developed methodical approaches for detecting the surface contamination of the wellbore with spectrometric gamma-logging were experimentally confirmed during the work on the installation of foundation pits.

Due to the use of spectrometric gamma-logging, volume of soils contamination as well as soils intervals located below active layer and design depth of the pit were reliably detected and identified. For such intervals in work [1], scientifically grounded recommendations were prepared in advance for

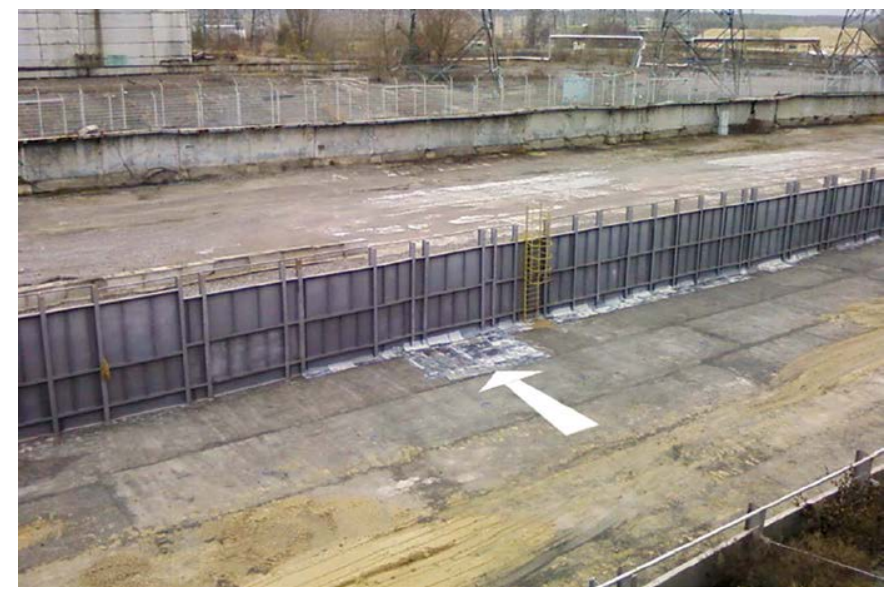

Fig. 8. An example of shielding with powerful gamma-radiation lead on sites [1] that were predicted due to gamma-and spectrometric gamma-logging results

the removal of contaminated soil layers from the bottom of the pits. But in the future, to reduce the gamma- radiation in the pit and optimize the volume of construction-installation works these areas were shielded with lead sheets (fig. 8).

On the basis of the results of spectrometric gammalogging, a classification was developed in which the levels and nature of the radioactive contamination of the soil of the foundation pits were reflected. This classification allowed to predict correctly the formation of radioactive during excavation works on the foundation pits foundation of the NSC [1]. During the analysis of the results of single measurements of gamma-spectrometric logging the uncertainty about the type of pollution (surface or volumetric) was noted. Therefore, additional measurements were made along the wellbore. It is the results of comparative analysis of gamma-ray spectra above or below the depth of the well from the interval of abnormally high values of the gamma-field that give confidence in determining the type of contamination.

\section{References}

1. Panasiuk M. I., Skorbun A. D., Litvin I. A. (2010). Radiological studies of soils in pits and wells. North and South tape NSC foundations. Research Report. SIP 09-2-001 NI 03 RPT 008 01. Archive GPM SIP of ChNPP. (in Russ.)

2. Bykov V. T., Golovnya V. Ya., Goncharov K. S., Kuzmenko V. A., Remaev V. V. (1998). [Control of the fuel content in massive samples of highly radioactive waste as to ${ }^{137} \mathrm{Cs}$ gamma-radiation]. Problemy Chornobylia [Problems of Chornobyl], vol. 2, pp. 97-99. (in Russ.)

3. Batiy V. G., Kuzmenko V. A. (2001). [Mathematic model- 
ing of radioactively contaminated grounds inventorying]. Problemy Chornobylia [Problems of Chornobyl], vol. 8, pp. 69-75. (in Russ.)

4. Panasiuk M. I., Pravdiviy O. A., Rudko V. M., Shestopalov V. M. (2001). Results of radio-hydrogeological monitoring in the local area of the Shelter facility and at the ChNPP site. Biuleten ekolohichnoho stanu zony vidchuzhennia ta zony bezumovnoho (oboviazkovoho) vidselennia [Bulletin of the ecological status of the Exclusion Zone and unconditional (compulsory) eviction], vol. 17, pp. 51-56. (in Ukr.)

5. Panasiuk M. I., Skorbun A. D., Pavlyuchenko M. I. (2003). [Use of spectrometric gamma logging for study of contamination spread structure in soils around ChNPP Unit 4]. Problemy Chornobylia [Problems of Chornobyl], vol. 13, pp. 116-119. (in Ukr.)

6. Panasiuk M. I., Skorbun A. D., Pavlyuchenko M. I. (2005). [Using of spectrometric gamma-logging for analysis of radioactive pollution sources of underground environment]. Zbirnyk naukovykh prats Instytutu yadernykh doslidzhen [Proceedings of the Institute of Nuclear Research], vol. 14, no. 1, pp. 144-149. (in Ukr.)

7. Skorbun A. D. (2013). [Scientific base for enhancement of validity of complex estimation of radioecological situation on radioactive contaminated territories (on the example of Shelter object)] (PhD thesis). Chornobyl, 35 p. (in Ukr.)

\section{О. І. Стоянов, М. І. Панасюк, В. Е. Іванова, Г. В. Левін, Н. В. Сосонна}

Інститут проблем безпеки АЕС НАН Украйни, вул. Кірова, 36а, Чорнобиль, 07270, Україна

\section{Застосування спектрометричного гамма- каротажу для уточнення характеристик радіоактивного забруднення грунтів}

Грунти поблизу 4-го блока Чорнобильської АЕС мають високі рівні радіоактивного забруднення і належать до радіоактивних відходів (РАВ) від низької до високої категорії. У таких грунтах було заплановано створення котлованів глибиною 3-4 м для фундаментів нового безпечного конфайнмента, за допомогою якого була створена нова захисна оболонка над зруйнованим блоком. Для планування технології земляних робіт, програм із радіаційної безпеки та поводження з РАВ виникла потреба в прогнозах радіаційних характеристик техногенних грунтів, які підлягали вилучен- ню під час розробки котлованів. При цьому основним методом уточнення характеристик РАВ був гаммата гамма-спектрометричний каротаж свердловин. Це спостережні свердловини радіогідроекологічного моніторингу та біля 700 свердловин, які були заздалегідь пробурені по периметру майбутніх котлованів через кожні 1,5 м для влаштування шпунтового огородження стінок виїмки.

Наведено досвід використання методу спектрометричного гамма-каротажу свердловин для оцінки радіоактивного забруднення грунтів. Аналіз співвідношення фотопік/комптон у спектрах гамма-поля по стовбуру свердловин дав змогу виділити типи забруднення грунтів: об'ємне, яке пов'язане з реальним радіоактивним забрудненням, та поверхневе, що ідентифікується як привнесене під час буріння свердловин. Це завдання особливо актуальне для визначення межі забруднених/чистих грунти, що мала вплив на визначення глибини котлованів та, як наслідок, на об’єми грунтів, що підлягали вилученню. За генетичними ознаками позитивні аномалії гамма-поля по стовбору свердловин можна розділити на три групи. Перша група характеризується наявністю другого піку на діаграмах гамма-каротажу, який свідчить про об’ємне забруднення грунтів, що оточують свердловину. Друга група - відносно високе поверхневе забруднення стінок свердловин за рахунок осипання активних часток грунтів із верхніх сильно забруднених шарів під час буріння. Третя група - поверхневе забруднення стінок свердловин досить незначне, практично на рівні «фонових» значень. Застосування спектрометричного гаммакаротажу дозволило розрізнити реальне забруднення грунтів від привнесеного та коректно спрогнозувати категорії та об'єми РАВ, які підлягали вилученню. Під час досліджень були виявлені ділянки, на яких реально забруднені грунти були розташовані нижче проектної глибини котловану. Під час земляних робіт їх додатково вилучали або екранували листами свинцю для зменшення радіаційного навантаження на персонал, що мав працювати в котлованах. Для збільшення інформативності спектрометричного гамма-каротажу свердловин необхідно проводити не тільки аналіз співвідношення фотопік/комптон, а й аналіз змінення форм фотопіка та комптонівської частини спектра залежно від відстані до активного шару та поверхні. Це є одним із напрямів подалышого вдосконалення методу спектрометричного гамма-каротажу для уточнення характеристик РАВ.

Надійшла 25.02.2020

Received 25.02.2020 